\title{
Environmental Regulation Effect on FDI Research - based on the Perspective of Local Government Competition
}

\author{
Peicai $\mathrm{Wu}^{1}$, a , Zhong Wang ${ }^{1}$, Yiou Huang ${ }^{2}$ \\ ${ }^{1}$ School of Economics and Management, South China Normal University, Guangzhou, China; \\ ${ }^{2}$ School of Economics and Management, University of South China, Hengyang, China. \\ awupeicai_keep@sina.com
}

\begin{abstract}
By using Chinese provincial panel data from 1998 to 2013, the study, based on the empirical analysis about the influence of environmental regulation on FDI, found that: the higher the degree of local government fiscal autonomy, the greater the incentive of the competition of FDI; strict environmental regulation has a bad effect on FDI inflows; in order to attract more FDI, local government especially in the central and western regions have the tendency to attract FDI by reducing the environmental regulation.
\end{abstract}

Keywords: FID; environmental regulation; financial autonomy.

\section{Introduction}

Since the tax reform in 1994, our country government has experienced a parallel mode contained special economic decentralization and political centralization, which gives local government both fiscal and promotion incentives. And local governments, therefore, take measures such as tax breaks, preferential land policy, environmental regulation reducing and other preferential policies to attract foreign investment in order to obtain the economic effect quickly. Based on this cognition, we cannot ignore the competition among local governments when studying the influence of environmental regulations on regional FDI inflows into China. We use regional environmental regulation, foreign direct investment and government autonomy indicators in panel data from 1998 to 2013, so that we can analyze the influence of environmental regulation on foreign direct investment in the competition among governments. After this introduction, the literature review is presented. The third part will present model and data. Then the conclusions are outlined and we will expound the policy implications in the final part.

\section{Empirical Study}

\subsection{Model.}

Our research is based on "pollution haven" theory, which means to find the optimal place to invest factories with less costs and max profit. As a result, the resources endowment of a region, the size of the market, the cost of production, and the political stability are usually those vital factors considered by FDI inflows. In order to inspect how environmental regulation influence FDI inflows, we would choose environmental regulation, local government competition model, and the environment regulation interaction with the local government competition to see whether local governments would lower the level of environmental regulation to compete for FDI. In addition, all variables would lag one period for that to avoid endogenous estimation problem, model set is as follows:

$$
\begin{aligned}
& \mathrm{F}_{\mathrm{it}}=\alpha+\beta_{1} \mathrm{E}_{\mathrm{it}-1}+\beta_{x} \mathrm{X}_{\mathrm{it}-1}+f_{i}+\varepsilon_{i t} \\
& \mathrm{~F}_{\mathrm{it}}=\alpha+\beta_{1} \mathrm{E}_{\mathrm{it}-1}+\beta_{2} \mathrm{G}_{\mathrm{it}-1}+\beta_{x} \mathrm{X}_{\mathrm{it}-1}+f_{i}+\varepsilon_{i t} \\
& \mathrm{~F}_{\mathrm{it}}=\alpha+\beta_{1} \mathrm{E}_{\mathrm{it}}+\beta_{2} \mathrm{G}_{\mathrm{it}-1}+\beta_{2} \mathrm{E}_{\mathrm{it} 1} \times \mathrm{G}_{\mathrm{it}-1}+\beta_{x} \mathrm{X}_{\mathrm{it}-1}+f_{i}+\varepsilon_{i t} \\
& \mathrm{~F}_{\mathrm{it}}=\alpha+\beta_{1} \mathrm{E}_{\mathrm{it}-1}+\beta_{2} \mathrm{E}_{\mathrm{it}-1}^{2}+\beta_{3} \mathrm{G}_{\mathrm{it}-1}+\beta_{4} \mathrm{E}_{i t-1} \times \mathrm{G}_{\mathrm{it}-1}+\beta_{x} X_{i-1}+f_{i}+\varepsilon_{i t}
\end{aligned}
$$


2.2 Variable Declaration (Table 1).

Table 1 Variable declaration

\begin{tabular}{ccccccc}
\hline Variable & Name & Observed Value & Average & S.E & Min & Max \\
FDI & Foreign direct investment & 480 & $-1.98 \mathrm{e}-10$ & 1 & -1.097 & 4.491 \\
LNE & Environmental Regulation Intensity & 480 & 9.695 & 0.913 & 7.914 & 12.15 \\
G & Governments' fiscal autonomy & 480 & 0.528 & 0.185 & 0.150 & 0.950 \\
SOE & state-owned enterprises' performance & 480 & 0.500 & 0.215 & 0.0996 & 0.906 \\
LNWAGE & Log(wage) & 480 & 9.841 & 0.668 & 8.591 & 11.45 \\
LNPERGDP & Log(GDP per person $)$ & 480 & 9.662 & 0.817 & 7.768 & 11.51 \\
LNGDP & Log(GDP) & 480 & 8.577 & 1.113 & 5.398 & 11.04 \\
OPEN & The degree of opening & 480 & 0.312 & 0.401 & 0.0309 & 1.800 \\
ROAD & Regional infrastructure & 480 & 0.0392 & 0.0925 & 0.000110 & 0.927 \\
\hline
\end{tabular}

This is the provincial panel data in China 1998-2013, including discharged data from the 《China environment Yearbook》, and the rest of the data are from 《Chinese statistic year book》 and calendar year database.

\section{Result}

Table 2 Regression results

\begin{tabular}{|c|c|c|c|c|c|c|}
\hline & \multicolumn{4}{|c|}{ Nation } & \multirow{2}{*}{$\begin{array}{c}\text { Eastern } \\
\text { RE5 }\end{array}$} & \multirow{2}{*}{$\begin{array}{c}\text { Midwest } \\
\text { RE6 }\end{array}$} \\
\hline & RE1 & RE2 & RE3 & RE4 & & \\
\hline LNE & $\begin{array}{c}-0.3274 * * * \\
(-6.26)\end{array}$ & $\begin{array}{c}-0.3287 * * * \\
(-6.54)\end{array}$ & $\begin{array}{c}-0.3315^{* *} \\
(-2.00)\end{array}$ & $\begin{array}{c}-0.3349 * * * \\
(-4.18)\end{array}$ & $\begin{array}{l}-0.1372 \\
(-0.52)\end{array}$ & $\begin{array}{c}-0.3730 \text { *** } \\
(-5.83)\end{array}$ \\
\hline SOE & $\begin{array}{c}-2.1724 * * * \\
(-9.58)\end{array}$ & $\begin{array}{c}-1.6452 * * * \\
(-7.06)\end{array}$ & $\begin{array}{c}-1.4262 * * * \\
(-5.73)\end{array}$ & $\begin{array}{c}-1.7224 * * * \\
(-6.93)\end{array}$ & $\begin{array}{c}-1.7496 * * * \\
(-3.01)\end{array}$ & $\begin{array}{c}-0.8045 * * * \\
(-4.04)\end{array}$ \\
\hline OPEN & $\begin{array}{c}0.1633 \\
(1.08)\end{array}$ & $\begin{array}{c}0.2325 \\
(1.47)\end{array}$ & $\begin{array}{c}0.2846^{*} \\
(1.85)\end{array}$ & $\begin{array}{c}0.2064 \\
(1.26)\end{array}$ & $\begin{array}{c}0.1845 \\
(0.72)\end{array}$ & $\begin{array}{c}-0.3475 \\
(-0.70)\end{array}$ \\
\hline LNPERGDP & $\begin{array}{c}0.9448 * * * \\
\quad(7.42)\end{array}$ & $\begin{array}{c}0.7131 * * * \\
\quad(5.59)\end{array}$ & $\begin{array}{c}0.6945^{* * *} \\
(5.14)\end{array}$ & $\begin{array}{c}0.6972 * * * \\
\quad(5.40)\end{array}$ & $\begin{array}{c}0.5164 \\
(1.01)\end{array}$ & $\begin{array}{c}0.3529 * * * \\
(4.30)\end{array}$ \\
\hline LNGDP & $\begin{array}{c}-0.4008 * * * \\
(-7.62)\end{array}$ & $\begin{array}{c}-0.5490 * * * \\
(-9.86)\end{array}$ & $\begin{array}{c}-0.5488 * * * \\
(-10.20)\end{array}$ & $\begin{array}{c}-0.5461 * * * \\
(-9.59)\end{array}$ & $\begin{array}{c}-0.7339 * * * \\
(-5.68)\end{array}$ & $\begin{array}{c}-0.2289 * * * \\
(-4.57)\end{array}$ \\
\hline LNWAGE & $\begin{array}{c}0.2690 \\
(0.96)\end{array}$ & $\begin{array}{c}0.1294 \\
(0.48)\end{array}$ & $\begin{array}{c}-0.1249 \\
(-0.73)\end{array}$ & $\begin{array}{c}-0.1494 * * \\
(-2.19)\end{array}$ & $\begin{array}{c}-0.6993^{* *} \\
(-2.24)\end{array}$ & $\begin{array}{c}-0.5500 * * \\
(-2.15)\end{array}$ \\
\hline ROAD & $\begin{array}{c}1.7510^{* * * *} \\
(4.43)\end{array}$ & $\begin{array}{c}1.5123 * * * \\
(-3.97)\end{array}$ & $\begin{array}{c}0.7374 * \\
(1.80)\end{array}$ & $\begin{array}{c}1.6547 * * * \\
(3.97)\end{array}$ & $\begin{array}{c}2.9969 * * * \\
(2.82)\end{array}$ & $\begin{array}{r}0.0059 \\
(0.02)\end{array}$ \\
\hline $\mathrm{G}$ & & $\begin{array}{c}2.5955^{* * *} \\
(6.30)\end{array}$ & $\begin{array}{c}3.1744 * * * \\
(8.08)\end{array}$ & $\begin{array}{c}2.4788^{* * * *} \\
(5.70)\end{array}$ & $\begin{array}{c}2.0068 \\
(1.55)\end{array}$ & $\begin{array}{c}1.7772 * * * \\
(4.40)\end{array}$ \\
\hline $\mathrm{LNE} \times \mathrm{G}$ & & & $\begin{array}{c}0.0766^{* *} \\
(2.03)\end{array}$ & $\begin{array}{c}0.1574 * \\
(1.89)\end{array}$ & $\begin{array}{l}-0.3027 \\
(-0.47)\end{array}$ & $\begin{array}{c}0.1998^{*} \\
(1.82)\end{array}$ \\
\hline (LNE)2 & & & & $\begin{array}{c}0.0079 * \\
(1.80)\end{array}$ & $\begin{array}{c}0.0571 \\
(0.86)\end{array}$ & $\begin{array}{c}0.0453 * * * \\
(3.48)\end{array}$ \\
\hline CONSTANT TERM & $\begin{array}{c}-6.9624 * * * \\
(-2.79)\end{array}$ & $\begin{array}{l}-3.5975 \\
(-1.47)\end{array}$ & $\begin{array}{r}-1.5350 \\
(-1.26)\end{array}$ & $\begin{array}{l}-3.5824 \\
(-1.43)\end{array}$ & $\begin{array}{c}-1.1281 \\
(-0.21)\end{array}$ & $\begin{array}{r}3.3887 \\
(1.30)\end{array}$ \\
\hline $\mathrm{N}$ & 464 & 464 & 464 & 464 & 176 & 288 \\
\hline $\mathrm{R} 2$ & 0.555 & 0.591 & 0.569 & 0.594 & 0.370 & 0.330 \\
\hline
\end{tabular}


Considering the results of the Hausman test, we chose the random effects model to eliminate the regional heterogeneity among different provinces. Results of regression based on model1-model4 are given in table 2. RE1-RE4 are the estimated results of model1-model4 based on the national sample, while RE5 and RE6 are the estimated results of model4 based on the sub-samples.

Model 1 only includes the environmental regulation and other control variables, and it indicates that the coefficient of environmental regulation is significantly negative, which means the weaker environmental regulation the more FDI inflows. On the other hand, Model 2 shows that the coefficient of local competition is significantly positive, suggesting that the financial power of local governments has a positive effect on the inflow of FDI. That's to say, local governments are prone to attract more FDI for the development of economy. Meanwhile, the absolute value of negative coefficient increases in model 2 compared with model 1, i.e., the explanatory power of the model is improved. We add the interaction of environmental regulation and local competition to model3, its regression result(RE3) also indicates that the environmental regulation has a significantly negative effects to FDI, which also proves that environmental regulation hinders the inflow of FDI, and while the interaction coefficient is significantly positive and larger than that appears in RE2. This can be explained as that the effect of regional environmental regulation on FDI will be weakened when local governments' autonomy was improved. Because that the current local governments under political and economic incentives have weakened regional environmental regulation, and they tend to introduce foreign investment. The quadratic environmental regulation added to model 4 represented the nonlinear influence of environmental regulation on FDI inflows. It is apparent that the coefficient of quadratic component is significantly positive, indicating that the influence of environmental regulation on FDI trajectory is "U" shape, i.e., ——in the left side of the turning point, environmental regulation mainly imposes inhibition on FDI, and vice versa. We believe that the strict environmental regulation brings high production cost to the enterprise and provide a good environment as a comparative advantage. And these will drive the enterprise to promote a cleaner production technology.

In RE5 and RE6, estimated coefficients of environmental regulation, based on the east and Midwest sample, are significantly negative, and so does coefficients of quadratic components, which are not significant in the estimation results based on the eastern sample. And the estimated results of environmental regulation, to a certain extent, proved the robustness of estimated results based on the national sample. The coefficients of autonomy of local government and its interaction with the environment regulation in RE6 are significantly positive, while they are non-significant in RE5. The difference between estimated results based on different regional samples suggests that local government, from the central and western regions, has a greater financial autonomy than that of the eastern regions. And we can explain this phenomenon from the following two aspects: firstly, since the level of economic development in the central and western regions is relatively lower than that of the eastern regions, governments in central and western regions, aiming to introduce FDI which can accelerate growth of local economy, have more passion than governments of eastern cities to reduce their environmental regulation; secondly, compared with the eastern regions, administrative regime of western and central governments have more defects--the government regulation is weak, and the public environmental awareness is not strong. The cost of sacrificing environment for economic in western and central regions is smaller than the eastern regions, and that is why governments in central and western regions are more willing to reduce regulation for more inflows of FDI.

Regarding to all control variables in the model, the proportion of state-owned enterprises' performance in GDP has a significantly negative coefficient and it is larger enough to show that state-owned enterprises' performance will have a larger extrusive effect on FDI. And the degree of regional marketization is also one of the most important factors to attract the inflow of FDI. If the proportion of state-owned economy in eastern region decrease one percentage, which can lead to the rise of 1.7 times of standard deviation on FDI, while the rest of the region will rise 0.8 times. The degree of opening has two different effects on FDI: the higher degree of opening is, on the one hand, 
the closer connection between the international market and the region will be; On the other hand, the higher degree of opening will bring more international competition that will inhibit the inflow of FDI.

\section{Conclusion}

In this paper, we inspect the effect of environmental regulation on FDI from the perspective of local government competition, the results are as follows: firstly, the strict environmental regulation indeed has an inhibitory impact on FDI inflows because FDI mainly inflows to the manufacturing industries which often make earnings at the cost of environment, and thus, governments, under weak supervision, will lose its environmental regulation in order to attract FDI inflows; secondly, the higher the autonomy of local government is, the more they will tend to reduce FDI environment regulation competition. And it should be noticed that relationship between environmental regulation and FDI changes as a "U" shape, the strict environmental regulation level will optimize the production technology and structure of FDI inflows. Meanwhile, the results also indicate that the central and western regions are undergoing a competition called "compete from the bottom", and the competition is more intense than the rest of the country. And the intense of these competitions is also strengthened by the increasing degree of the fiscal autonomy.

\section{References}

[1] Copeland, B., Taylor, M. North-South Trade and the Environment [J].The Quarterly Journal of Economics, 1994, 109(3):755-787.

[2] Xing Y,Kolstad C. Do Lax Environmental Regulations Attract Foreign Investment? [J]. Environmental and Resource Economics, 2002, 21(1):1-22.

[3] Smarzynska B., Wei S. J. . Pollution Havens and Foreign Direct Investment: Dirty Secret or Populat Myth? [R]. NBER Working paper, No.8465.

[4] Manderson, E., Kneller, R. Environmental Regulations, Outward FDI and Heterogeneous Firms: Are Countries Used As Pollution Havens. Environmental and Resource Economics, 2012, 51(3):317-352.

[5] Kirkpatrick, C., Shimamoto, K. The Effect of Environmental Regulation on the Locational Choice of Japanese Foreign Direct Investment. Applied Economics, 2008, 40:1399 - 1409. 